\title{
ANALYSIS OF INTERNATIONAL INDEX ON INDONESIAN SHARIA STOCK INDEX
}

\author{
Shofal Iman ${ }^{a}$ \\ Imron Mawardi ${ }^{\text {b }}$ \\ Md Atiqur Rahman Sarkerc \\ a,b Islamic Economics, Faculty of Economics dan Business, University of Airlangga \\ 'Department of Business Administration, East West University, Bangladesh \\ Email: shofaliman@yahoo.com; ronmawardi@feb.unair.ac.id; mars@ewubd.edu
}

\section{ARTICLE HISTORY}

Received:

3 January 2019

Revised:

27 May 2020

Accepted:

27 May 2020

Online available:

30 June 2020

Keywords:

Dow Jones Industrial

Average,

Hang Seng Index,

Indonesian Sharia Stock

Index,

Nikkei 225,

Error Correction Model

*Correspondence:

Name: Shofal Iman

E-mail:

shofaliman@yahoo.com

\section{ABSTRACT}

This study aims to determine the influence of long-term and short-term global stock index on the Indonesian Islamic stock index. The approach used is a quantitative approach and uses the Error Correction Model (ECM) method. ECM is an analytical model that can be used in time series data to estimate the effect of independent variables on long-term and short-term use variables. The sample used was taken from secondary data, namely global stock index data consisting of the DJIA, N225 and HSI indices, and the Indonesian sharia stock index in the form of the ISSI index in the period of January 2013 to December 2017, so that 60 samples were obtained. The test results show that in the long run, the DJIA and HSI indices have a significant positive effect on the ISSI index, while the N225 index has a significant negative effect on the ISSI index. In the short term, only the DJIA index has a significant positive effect on the ISSI index.

\section{INTRODUCTION}

Investment is an activity that aims to develop assets. Owned assets are currently invested in the hope of earning benefits that can be utilized later on. Investment is different from saving. In general, saving is depositing assets owned by a bank so that it can be utilized if needed later on (Adlan \& Mawardi, 2018). This difference also lies in investments that have a higher risk than saving. The flow of funds from an investment will be utilized in a business that is always faced with profit or loss.

Decision making with consideration has been explained in Q.S. Al-Hasyr verse 18. This verse explains that decision making must really be taken into account because it will 
have an impact on oneself in the future. This also applies to investment decisions. An investor needs to think carefully in determining the direction of investment because this activity is related to the commitment of a number of funds or other resources carried out at this time in order to obtain a number of benefits in the future (Tandelilin, 2010). The future is indeed uncertain so humans need to prepare early to face the future. One of them is by investing. Investment is also an active form of Islamic economic activity and is an effort in realizing mashlahah. The assets invested will benefit many people. The investment must certainly be in accordance with Islamic law.

Various securities can be chosen by investors as a means of investing, but securities that are in accordance with Islamic sharia are effects originating from the Islamic capital market. The Islamic capital market in Indonesia is not a separate system from the overall capital market system. In general, sharia capital market activities do not have differences with conventional capital markets, but have certain characteristics, such as products and transaction mechanisms that do not conflict with sharia principles. Basically the Indonesian Islamic capital market is part of the capital market industry in Indonesia. The Islamic capital market also acts as a source of funding for companies and investment facilities for investors.

Indonesia is a country with a Muslim majority population and the most in the world. This indirectly has a positive impact on the development of the Islamic capital market in Indonesia. It was proven that in $\mathbf{2 0 1 6}$ the Indonesian capital market experienced significant growth. The number of Islamic investors in the Indonesia Stock Exchange (IDX) increased $150 \%$ to 12,283 as of the end of 2016 from 2015 which was only 4,908. Compared to 2012 when there were 531 sharia investors, there was an increase of $2.751 \%$ up to April 2017 with 15.141 sharia investors (Dzanurrahmana Zein, et al., 2019).

One of the factors that influence the development of the Islamic capital market in Indonesia is the attractive effects offered to potential investors. One effect on the Islamic capital market that is much sought after by potential investors is Islamic stocks (Mawardi, et al., 2019). Investors who invest in Islamic stocks certainly want to get profits and minimize the existing risks. Based on the statement, investors need guidance in practice.

Investment guidelines are an absolute necessity for an investor. One form of guidelines for investing in Islamic stocks is the Islamic stock index. There are two sharia stock indices in Indonesia, namely the Jakarta Islamic Index (JII) and the Indonesian Sharia Stock Index (ISSI). Even though JII was published first, ISSI is an indicator of the overall performance of the Indonesian sharia stock market. All shares in the Sharia Securities List / Daftar Efek Syariah (DES) issued by the Financial Services Authority / Otoritas Jasa Keuangan (OJK) by the IDX are included on ISSI. Shares included in ISSI are in accordance with the National Sharia Council Dewan Syariah Nasional Fatwa (DSN) of the Indonesian Ulema Council / Majelis Ulama Indonesia (MUI) No: 80 / DSN-MUI / III / 2011 concerning the Application of Sharia Principles in the Equity Securities Trading Mechanism in the Regular Stock Exchange Market. ISSI shares are reviewed twice a year, every May and November 
following the DES review schedule. The ISSI calculation method is a weighted average of market capitalization using December 2007 as the base year of calculation.

Investors who will invest their capital in Islamic stocks cannot ignore the current global economic conditions. The global economic conditions that are often erratic cause global capital markets to be affected, given the Indonesian Islamic capital market is part of the global capital market. The link between the Indonesian capital market and the foreign capital market began after investors were allowed to take control of shares listed on the Jakarta Stock Exchange (now the Indonesia Stock Exchange) (Majdoub, et al., 2016). In today's global market, an investor can invest wherever he is (capital does not carry any flag) (Rusmita, et al., 2020). Globalization has also allowed investors from other countries to invest in Indonesia so that changes in the value of an exchange will also be transmitted to other countries' exchanges. Larger stock exchanges will affect smaller stock exchanges (Pasaribu, 2008).

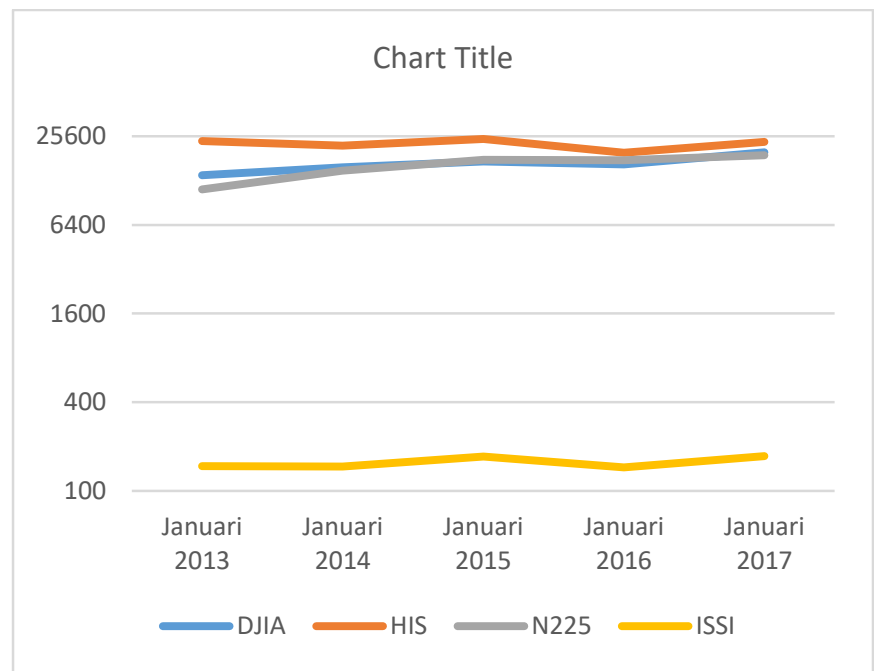

Figure 1. Development of DJIA, HSI, N225, ISSI Stock Index 2013-2017 Source: id.investing.com

On the graph there are three global indices namely the Dow Jones Industrial Average (DJIA), Nikkei 225 (N225), and the Hang Seng Index (HSI). The three global indices have relatively the same price shifts, as seen in January 2015 to January 2016. In that period, all three indices experienced a downtrend (bearish), while in January 2016 to January 2017 experienced an upward trend (bullish). Even though the ISSI index is far below, the movement of the trend tends to follow the three global indices. The movement of the global index needs to be considered by every global investor so that it will influence its investment decisions.

The global index is a general description of global economic conditions, especially reflecting the general conditions of each exchange. The DJIA index from America, N225 from Japan, and HSI from Hong Kong are three important indices that are of concern to all global investors, especially investors who invest in the Indonesian stock exchange, because these three indices come from countries that have a big influence on the Indonesian economy. The strong influence of DJIA, N225, and HSI on ISSI is the background of this research. 
Researchers want to see the short-term and long-term effects of global indexes on ISSI, seeing the three indexes are larger indices than ISSI. Based on this background, this study raises the title Analysis of Global Stock Market Influence on the Indonesian Sharia Stock Market with the Error Correction Model Approach. This study will look at whether the global stock market has a long-term effect on the Indonesian sharia stock market, and see whether the influence of the global stock market on the Indonesian sharia stock market in the short term corrects its long-term influence.

\section{LITERATURE REVIEW}

The stock market index is an indicator used to measure the daily performance of a group of shares in a country's industry, sector, or overall stock market. According to Darmadji and Hendy (2011), stock price movements can be described by the stock market index. In the capital market a stock market index has five functions, namely 1) as an indicator of market trends, 2) as an indicator of profitability, 3) as a benchmark for the performance of a portfolio, 4) facilitate the formation of portfolios, and 5) facilitate the development of derivative products.

In conventional capital markets and Islamic capital markets, information has an important role because it can influence investor decisions in determining investment strategies (Mawardi, et al., 2019). Complete, relevant, accurate, and timely information is needed by investors. One form of information needed is stock price movements using the stock market index. Frensidy (2013) states that events in the stock market can be reflected in indicators that are often used, namely the stock market index. The establishment of a stock market index aims to represent the movement of all shares or certain shares in a stock exchange (Rusmita, et al., 2019).

The study of Umam, et al. (2019) discusses that there are several factors that affect stock price movements or stock price indexes, namely internal factors and external factors. Internal factors discuss announcements about marketing, production, sales such as advertising; contract details; price changes; withdrawal of new products; production report; product safety report; and sales report. In addition, there are funding announcements related to equity and debt. Announcement of management-board of director announcements announcing the changes and changes in directors, management, and organizational structure. There have also been announcements of diversification takeovers, such as merger reports, equity investments, take over reports by acquisition and acquisition, divestment reports, and others. Investment announcements that do plant expansion, research development, and other business closures. Job announcements or labor announcements that deal with new negotiations, new contracts, strikes, and others. Announcement of the company's financial statements, such as forecasting earnings before the end of the fiscal year and after the end of the fiscal year, earnings per share (EPS) and dividends per share (DPS), price earning ratio, net profit margin, return on assets (ROA), etc. other. 
In addition to internal factors, there are also external factors. First, announcements from the government such as changes in interest rates on savings and deposits, foreign exchange rates, inflation, and various regulations and economic deregulation issued by the government. Second, legal announcements, such as the demands of employees against the company or against its managers and the company's demands on its managers. The three securities industry announcements, such as annual meeting reports, insider trading, trading volume or price, trading restrictions / delays. Fourth, domestic political turmoil and exchange rate fluctuations are also factors that have a significant influence on the occurrence of stock price movements in a country's stock exchange.

Stock market indices in choosing the samples taken must be representative, although not many. If the representative sample has been selected, it is necessary to weigh the stocks in the sample to be used in calculating the index of a particular stock or industry. There are three ways of weighting that can be used, namely 1) weighted based on price (price-weighted), 2) weighted based on market capitalization (value weighted), and 3) unweighted or equal weighted (unweighted or equal-weights).

Signaling theory explains that the importance of a key information for investors is given by a manager. Good information that is owned by a manager about a company needs to be conveyed to investors with the intention that the stock price increases (Rusmita, et al., 2019; Sugiarto, 2009). Signals in the form of good and bad information can influence investor confidence and behavior in investment decisions. An investor will react to information received, whether it is good or bad. Good information received by external parties will give a positive signal. This positive signal is based on high market reaction which can increase the stock market index. Conversely, negative signals received by investors will be responded to by a negative stock market reaction to the company.

Contagion effect is a significant increase in relations between markets after a shock to a country (Dornbusch, et al., 2000). Economic conditions in one country can affect the economy of another country. Indonesia as a country that has economic relations with many other countries is certainly very dependent on global economic conditions, especially those relating to investment. The capital market in Indonesia, which is not only owned by domestic investors, but also foreign investors, is certainly very sensitive to the state of the global economy, especially developed countries.

The effect of contagion effect on the capital market, especially stocks, arises when there are international stock investments, namely investments in shares in several countries so that investment decisions in one country can affect investments in other countries. Investors who invest not only in one country will certainly be guided by the global stock market index to determine the direction of investment. The movement of the stock market index in a country, especially countries that have an important role in the global economy, tends to be contagious to other countries.

\section{Hypothesis and Analysis}


Based on the background, problem formulation, theoretical basis, and previous research, the formulation of the research hypothesis is as follows:

H1: DJIA, N225, and HSI indexes have a short-term effect on ISSI.

H2: DJIA, N225, and HSI indexes have a long-term effect on ISSI.

While the analysis model used in this study are:

$$
\begin{array}{ll}
I S S I_{t} & =\beta_{0}+\beta_{1} D J I A_{t}+\beta_{2} N 225_{t}+\beta_{3} H S I_{t}+\epsilon_{t} \ldots .(1) \\
& \text { Information: } \\
I S S I_{t} & : \text { Indonesian Syariah Stock Index period } \mathrm{t} \\
D J I A_{t} & : \text { Dow Jones Industrial Average period } \mathrm{t} \\
N 225_{t} & : \text { Nikkei } 225 \text { period } \mathrm{t} \\
H S I_{t} & : \text { Hang Seng Index periode } \mathrm{t} \\
\beta \quad & : \text { Parameter } \\
\mathrm{t} & : \text { Research period } \\
\epsilon \quad & : \text { Error term }
\end{array}
$$

\section{RESEARCH METHODS}

\section{Research Approach}

The approach used in this research is descriptive quantitative approach. Quantitative approach is a research method that is based on the philosophy of positivism that is used to examine populations or certain samples by collecting data using research instruments and using quantitative / statistical data analysis that aims to test hypotheses that have been established (Sugiyono, 2014). Data analysis method used in this study uses Error Correction Model (ECM) using monthly data. The use of ECM aims to determine the short-term and long-term effects of the independent variables, namely the DJIA index, N225, and HSI on the dependent variable ISSI by using Eviews 8.

Table 1

Operational Definition

\begin{tabular}{cc}
\hline No. & Indeks \\
\hline 1. & Dow Jones Industrial Average (DJIA)
\end{tabular}

DJIA is one of the oldest stock market indexes listed on the New York Stock Exchange (NYSE). DJIA data uses the closing price (close price) on the day before the last day of closing ISSI every month in the period January 2013 to December 2017 and is taken from the site id.investing.com.

2. Nikkei 225 (N225) N225 is a stock market index for the Tokyo Stock Exchange (TSE). N225 data uses the closing price (close price) on the last day of each month in the period January 2013 to December 2017 and is taken from the site id.investing.com.

3. Hang Seng Index (HSI)

$\mathrm{HSI}$ is a stock market index for the Hong Kong Stock Exchange (SEHK). HSI data uses the closing price (close price) on the last day of each month in the period January 2013 to December 2017 and is taken from the site id.investing.com.

4. Indeks Saham Syariah Indonesia (ISSI) ISSI is an index of Islamic stocks listed on the Indonesia Stock Exchange (IDX). ISSI data uses the closing price (close price) on the last day of each month in the period January 2013 to December 2017 and is taken from the site id.investing.com.

Source: investing.com 


\section{Data Types and Sources}

This study uses secondary data published by the website id.investing.com. The number of observations used is 60 observations which are time series data monthly from 2013-2017.

\section{Population and Sample}

The population used in this study is the entire index data of DJIA, HSI, N225, and ISSI. The research period uses data from January 2013 to December 2017 so there are 60 observations. Determination of the sample using purposive sampling method, the method is done deliberately in accordance with the required conditions and the availability of existing data. The sample uses DJIA, HSI, N225, and ISSI Index data by limiting the data the end of each month during the observation period from January 2013 to December 2017. This period was chosen because of the availability of complete data to obtain results that are in accordance with current conditions.

\section{Data analysis Technique}

\section{Unit Root Test and Integration Degree}

Stationarity testing is important in time series data analysis. Stationarity test can be done with a formal procedure, namely the unit root test. Ariefianto (2012) said that this procedure aims to verify that the data generating process (DGP) is stationary. Viewed from the economic side, this test aims to determine the behavior of the data if it is not stationary at the level of level, but stationary at the level of difference, indicating that the data moves randomly with deviations or constant changes because it shows the existence of influencing factors (Ekananda, 2016).

The regression from one variable to one or more variables produces spurious results, then it shows the existence of spurious regression (spurious regression) (Gujarati, 2004). In addition to the actual data behavior, it does not only show simple behavior that can be explained if the data is stationary at the data level, lancing regression also arises because of the apparent impact of regression using simple techniques (Ekananda, 2016). Stationarity test in this study was conducted by testing the unit roots using the Augmented Dickey-Fuller test (ADF) method.

This ADF method has the estimated regression equation as follows (Gujarati, 2004):

$$
\Delta Y_{t}=\alpha_{0}+\gamma Y_{t-1+1}+\sum_{t-1}^{p} \beta_{i} \Delta Y_{t-i+1}+\varepsilon_{t}
$$

The equation compares the results of the ADF test which calculates the calculated statistical value (t statistic) of the coefficient $\gamma$ with the critical value or Mackinnon critical value of $1 \%, 5 \%$, and $10 \%$. If the ADF test result is smaller than the critical value, $\mathrm{HO}$ is accepted and $\mathrm{H} 1$ is rejected, indicating the data is not stationary at the related level. When the data is not stationary at the related level, a test on the first difference must be repeated 
to obtain stationary data by reducing the data with the previous period data (Gujarati, 2004).

\section{Cointegration Test}

The next stage in this research is the cointegration test. Cointegration according to Ariefianto (2012) is a long-term relationship or equilibrium between variables that are not stationary. A set of variables can deviate from the equilibrium pattern, but it is hoped that there is a long-term mechanism that returns the variables to the equilibrium relationship pattern.

The Engle and Granger (1987) method will be used to test the cointegration in this study. The initial stage of the Engle and Granger cointegration test is the regression of the longterm equation or OLS to get the residual from the equation. The next stage is intended to determine whether the residuals of the above equations are stationary by conducting the Augmented Dickey Fuller (ADF) test. The dependent variable with the independent variables in this research are said to be cointegrated if the P-value in this test is smaller than $\alpha$ or 0.05 .

\section{Error Correction Model (ECM)}

Error Correction Model (ECM) is an analytical model that is widely applied in economic analysis. ECM is an analysis model that can be used in time series data to estimate the effect of independent variables on the dependent variable in the long run and short run. Differences in the consistency of forecasting results between short-term and long-term by means of the proportion of disequillibrium in one correction period and the next period so that no information is eliminated until the use for long-term forecasting using ECM (Jansen, 1996).

According to Ekananda (2016), the use of ECM has a close relationship with the concepts of stationarity and cointegration. In economic research, the use of stationarity and cointegration tests is not only based on econometrics procedures, but also based on research problems. Here are justifications for using ECM that can be used as research problems:

1. Researchers want to see whether time series economic data has a long-term trend / balance;

2. Researchers see that time series economic data fluctuations move around long-term trends / equilibrium, researchers want to see whether time series data undergo adjustments and corrections to long-term equilibrium or a particular reference. This particular reference can come from various things including:

a. Long term trend. This model is most often used because theoretically, a variable has a long-term phenomenon.

b. Expectations. This model shows that there is a tendency for variable fluctuations to follow the expectations of economic actors. 
c. Average. This example is easiest but not dynamic because it is based on static averages;

3. There is a theoretical background that can show that time series data can have longterm balance;

4. The existence of deviations (errors) that continue throughout the time of observation (some literature mentions this deviation as a form of imbalance to the long term or commonly called disequilibrium condition) to the long-term trend during observation.

a. These deviations can theoretically show a short-term fluctuation correction over the long run.

b. There is a theoretical background that should indicate a variable correction over the long run;

5. The existence of variable adjustments to the long-term trend.

a. Adjustment symptoms are based on a theoretical basis, ie variables always adjust to long-term balance.

b. Adjustments have a speed (spend of adjustment), which is the speed of adjustment to the long-term balance.

Long-term and short-term effects can be seen from the significance of the ECM test results. If the statistical probability of the $F$ test is smaller than $\alpha$ or 0.05 , the estimation of the model using ECM is simultaneously significant, while the partial significance occurs when the probability value for the t test statistic for each variable is smaller than $\alpha(0.05)$.

\section{Coefficient of Determination $\left(\mathbf{R}^{2}\right)$}

The coefficient of determination (R2) explains how much the percentage of the total variance of the dependent variable is explained by the model. $R 2$ values range from 0 to 1 . If R2 approaches or even has a value of 1 , the independent variable can explain the dependent variable more perfectly. Conversely, R2 that approaches or has a value of 0 indicates an independent variable that is getting weaker or unable to explain the dependent variable.

\section{RESULTS AND ANALYSIS}

\section{Stationary Test Results}

Data stationarity test is done through unit root test (unit root) and degree integration test. Stationarity test conducted by the Augmented Dickey-Fuller Test (ADF) method generally uses the following hypothesis:

$\mathrm{HO}$ : there is a root unit (time series data is not stationary)

$\mathrm{H} 1$ : no root unit (stationary time series data)

Hypothesis testing can be done by comparing $\alpha(1 \%, 5 \%$, and $10 \%)$ with $p$-value (probability) on the ADF statistical test. If the $\mathrm{p}$-value (probability) in the ADF is less than $\alpha=$ $1 \%, 5 \%$, and $10 \%$, the $\mathrm{HO}$ hypothesis is rejected so the data is stationary. If a unit root occurs, a second test needs to be done, namely the degree of integration test at the first difference level. 
Table 2

Root Level Unit Test Results Level

\begin{tabular}{|c|c|c|c|}
\hline \multirow{2}{*}{ Variable } & \multirow{2}{*}{ Level } & ADF test statistic & \multirow{2}{*}{ Probability } \\
\hline & & Intercept & \\
\hline \multirow{2}{*}{ ISSI } & Level & -1.690975 & 0.743 \\
\hline & First Difference & -6.430459 & 0.0000 \\
\hline \multirow{2}{*}{ DJIA } & Level & -0.532583 & 0.9792 \\
\hline & First Difference & -8.155142 & 0.0000 \\
\hline \multirow{2}{*}{ N225 } & Level & -2.163187 & 0.5006 \\
\hline & First Difference & -6.815979 & 0.0000 \\
\hline \multirow{2}{*}{$\mathrm{HSI}$} & Level & -1.286963 & 0.8815 \\
\hline & First Difference & -6.976773 & 0.0000 \\
\hline
\end{tabular}

Source: Output Eviews 8

The root unit root test results using the ADF method show that there is no single stationary variable at the level of level by comparing the probability of each variable with $\alpha$ $=1 \%, 5 \%$, and $10 \%$. This can be seen from the greater probability value of each variable, namely 0.743 for the ISSI variable, 0.9792 for the DJIA variable, 0.5006 for the N225 variable, and 0.8815 for the HSI variable for $\alpha=1 \%, 5 \%$, and $10 \%$. Seeing all the variables are not stationary at the level level, then the integration degree test at the first difference level needs to be done. At the first difference or lag 1 level, the results of the unit root test using the ADF method show that all stationary variables are at $\alpha=1 \%$ with a probability of 0.0000 .

\section{Cointegration Test Results}

Cointegration testing is done because there is a possibility that when all the variables in the study do not show stationarity at the level of the level can be stationary when all variables combine linearly. The combination of all variables is called a residual. Cointegration testing in this study was carried out using the Engle-Granger (EG) cointegration test. The dependent variable with the independent variables in this research are said to be cointegrated if the cointegration test using the Engle-Granger (EG) method yields a P-value smaller than $\alpha$ of 0.05 . The cointegration test results in this study are as follows:

Table 3

Residual Cointegration Test Results

\begin{tabular}{llcr}
\hline & t-Statistic & Probability \\
\hline $\begin{array}{l}\text { Augmented Dickey-Fuller test } \\
\text { statistic }\end{array}$ & -7.958726 & 0.0000 \\
Test critical values & $1 \%$ level & -4.124265 & \\
& $5 \%$ level & -3.489228 & \\
& $10 \%$ level & -3.173114 & \\
\hline
\end{tabular}

Source: Output Eviews 8 
Table 3 shows that based on cointegration testing, a P-value of 0,000 is obtained which is smaller than $\alpha$ of 0.05 . These results indicate that between the dependent variable and the independent variable in this study indicate the occurrence of cointegration, so that there is a long-term balance relationship between the ISSI variables with DJIA, N225, and $\mathrm{HSI}$. Based on the results of cointegration, analysis with the ECM method can be done.

\section{ECM Estimation Results}

The next step is to form ECM. There are several ECM methods developed from econometrics experts, but this study will use the ECM method developed by Engle-Granger (EG two-step model). The estimation results of the model formed from the ECM method are as follows:

Table 4

\begin{tabular}{|c|c|c|}
\hline \multicolumn{3}{|c|}{ Long-term Error Correction Model (ECM) } \\
\hline Variable & Coefficient & Probability \\
\hline DJIA & 0.006749 & 0.0000 \\
\hline N225 & -0.003644 & 0.0000 \\
\hline $\mathrm{HSI}$ & 0.001503 & 0.0187 \\
\hline C & 69.99893 & 0.0000 \\
\hline F-statistic (Probability) & 0.000000 & \\
\hline
\end{tabular}

Source: Output Eviews 8

Table 4 shows that the estimation of the long-term ECM model yields a P-value for the $F$ test statistic of 0,000 which is smaller than $\alpha(0.05)$ or simultaneously significant. Partially, the P-values for the t test statistics for the DJIA, N225, and HSI variables were $0,000,0,000$, and 0.0187 , respectively. All three results have values smaller than $\alpha$ or 0.05 so it can be said that the estimation of the ECM model is partially significant. This shows that DJIA, N225, and HSI have a significant effect on ISSI in the long run. Estimates of the shortterm ECM model are as follows:

$$
I_{S S I}=69,99893+0,006749 \text { DJIA }_{t}-0,003644 N 225_{t}+0,001503 H I_{t}+\varepsilon_{t}
$$

The equation shows that the DJIA variable has an influence on ISSI on the long-term relationship of 0.006749 . The magnitude of this influence indicates that an increase in the DIIA index by one unit will increase the ISSI index by 0.006749 . The N225 variable gives effect to ISSI of -0.003644 . The magnitude of this influence indicates that an increase in the N225 index by one unit will reduce ISSI by 0.003644 . Likewise, the increase in the HSI variable will have an influence on ISSI. The magnitude of this influence indicates that an increase in HSI by one unit will increase the ISSI index by 0.001503 . 
Table 5

Short-term Error Correction Model (ECM)

\begin{tabular}{lcc}
\multicolumn{1}{c}{ Variable } & Coefficient & Probability \\
\hline D(DJIA) & 0.003752 & 0.0304 \\
D(N225) & -0.000915 & 0.3971 \\
D(HSI) & 0.000225 & 0.7522 \\
RESID01(-1) & -0.267039 & 0.0023 \\
C & 0.223931 & 0.7422 \\
F-statistic (Probability) & 0.002333 & \\
\hline
\end{tabular}

Source: Output Eviews 8

The results in Table 5 show that the estimation of the short-term ECM model is valid or acceptable because it has a negative coefficient and a significant P-value $(0.0023$ is less than $\alpha$ or 0.05$)$. The RESID01 coefficient $(-1)$ of -0.267039 shows that the effect in the short term corrects $26 \%$ of past errors for the long term effect. Simultaneously, the P-value for the $F$ test statistic shows a value of 0.002333 or smaller than $\alpha(0.05)$ so that it can be said that the estimation of the model using short-term ECM is significant simultaneously. In addition, partially the P-value in the t-test $D$ (DJIA) statistic is 0.0304 or smaller than $\alpha(0.05)$ so it can be said that the variable has a significant effect on ISSI. P-values for $t$ test statistics for $D(N 225)$ and $D(H S I)$ are 0.3971 and 0.7522 , respectively, greater than $\alpha$ or 0.05 , so it can be said that there is no significant effect between D (N225) and D (HSI) against ISSI in the short term. Therefore, the next step is to estimate the new short-term model using only the $D$ variable (DJIA) as the independent variable as follows:

Table 6

Latest Short Term Error Correction Model (ECM)

\begin{tabular}{lcc}
\hline \multicolumn{1}{c}{ Variable } & Coefficient & Probability \\
\hline D(DJIA) & 0.003109 & 0.0101 \\
RESID01(-1) & -0.271698 & 0.0015 \\
C & 0.186936 & 0.7803 \\
F-statistic (Probability) & 0.000324 & \\
\hline
\end{tabular}

Source: Output Eviews 8

Table 6 shows that the estimation of the latest short-term ECM model that only uses the $D$ variable (DIIA) and removes the insignificant independent variable. The results show that the effect in the short term corrects $27 \%$ of past errors to its long-term effect, as seen from the RESID01 value (-1) of -0.271698 . Simultaneously, the P-value for the F test statistic is 0.000324 or smaller than $\alpha(0.05)$. These results indicate that the estimation of the model using a short-term ECM is significant simultaneously. In addition, partially, the P-value for the $t$ test statistic on the $D$ variable (DJIA) is 0.0101 which is smaller than $\alpha(0.05)$, so it can be said that there is a significant influence between $D$ (DJIA) on ISSI. Estimates of the shortterm ECM model are as follows: 
$D(I S S I)_{t}=0,186936+0,003109 D(D J I A)_{t}+\varepsilon_{t}$

The equation above shows that in the short-term relationship, the DJIA variable gives effect to ISSI by 0.003109 . The magnitude of this influence indicates that the DJIA index which rose by one unit, will increase the ISSI index by 0.003109 .

\section{The coefficient of determination results $\left(\mathbf{R}^{2}\right)$}

The coefficient of determination contained in the long-term and short-term ECM models are used as a measure of the goodness of the model. The coefficient of determination explains how much the diversity of the dependent variable in the model of the two equations can be explained by the independent variables. The coefficient of determination in the model of the two equations is shown through the adjusted R-square value. The coefficient of determination of the model in the two equations is as follows:

Table 7

Coefficient of Determination

\begin{tabular}{cc}
\hline Influence & R-squared value \\
\hline Short-term influence & 0.222663 \\
Long-term influence & 0.679858
\end{tabular}

Source: Output Eviews 8

The coefficient of determination shown through the adjusted R-square value illustrates the long-term and short-term relationships of the independent variables that significantly influence the dependent variable. The results obtained adjusted R-square value of 0.679858 . The meaning of this value is the diversity of the dependent variable in the model can be explained by the independent variables of $67.9858 \%$ while the other $32.0142 \%$ is explained by the variables that are not in the model. Short-term relationship is illustrated by the adjusted R-square value of 0.222663 . The diversity of the dependent variables in the model can be explained by the independent variables at $22.2663 \%$ while $77.7337 \%$ explained by other variables that are not in the model.

\section{Analysis}

The Influence of the Global Stock Market Against the Indonesian Sharia Stock Market for the 2013-2017 Period in the Long Term

Three indices, such as DJIA, N225, and HSI, represent the global stock market in this study. The results of data processing in Table 4 show that the three indices have a significant effect on ISSI in the long run both simultaneously and partially. The P-value for the F test statistic of 0.000 which is smaller than $\alpha$ of 0.05 shows that the estimation of the model using a long-term ECM is significant simultaneously. P-values for $t$ test statistics for DJIA, $\mathrm{N} 225$, and HSI variables were $0.000,0.000$, and 0.0187 which were smaller than $\alpha$ of 0.05 , respectively, indicating that the estimation of the ECM model was partially significant. 
The results of data processing in this study have similarities with previous studies. One of them is a study by Nurwulandari and Fuadi (2013) which states that the DJIA and N225 indices have a significant long-term effect on the CSPI. In addition, there is another study from Murti (2017) which states that the HSI and DJIA indices have a significant effect on the CSPI simultaneously and partially. Also strengthened research from Antonio et al. (2013) which states that the DJIA, HSI, and Nikkei indices have a significant simultaneous effect, but only partially the DJIA and HSI indices have a significant effect on the CSPI. ISSI is a part or scope of $\mathrm{JCl}$ or indexes in Indonesia in general, of course, has a tendency to move that is almost the same in the long run.

The tendency of the movement of ISSI which is one of the benchmarks of the Indonesian Islamic stock market in the long run cannot be separated from the influence of global stock market conditions. The results of this study serve as evidence that global stock markets such as DJIA, N225, and HSI are still the main reference, especially for the Indonesian sharia stock market when determining the direction of investment in the long run. These three indices have an influence on the decision of sharia stock market investors in Indonesia in investing.

In the long-term ECM equation it can be concluded that the DJIA and HSI indices show an up or down movement and influence the ISSI to follow the direction of movement of the two indices. The DJIA index gives an influence on ISSI by 0.006749 while the HSI index gives an effect of 0.001503 . The DJIA index from America and HSI from China are two indices originating from two countries that have a strong influence on the global economy, so developing countries like Indonesia are also affected.

However, different results are shown by the N225 index which tends to contradict the ISSI movement. When the N225 index has increased, the ISSI index has decreased and vice versa. These results confirm research conducted (Andiyasa, et al., 2014) which states the N225 index has a significant and negative effect on the JCl. Andiyasa, et al. (2014) argues that one of the causes of the N225 index having a negative influence on the $\mathrm{JCl}$ was the state of the Japanese economy during the study period. Investors who invest in several countries will certainly consider more profitable countries. The opposite movement between the N225 index and ISSI was clearly seen in 2014. The condition of the Indonesian stock market in the first quarter of 2014 was considered to be generally improving. On the other hand, the Japanese stock market at the same time tended to decline, given that it had only just emerged from the economic recession in the last quarter.

The difference in the long-term effect between the N225 index and the DIIA and HSI indices on ISSI shows that the global economy, especially for each country, can vary. The majority of countries may experience an increase, but there are some contrary to the decline, or vice versa. Uncertainty that occurs in the global economy such as the meaning contained in the letter Luqman verse 34 . Humans can only try, but the results obtained will be determined by God. The letter Luqman verse 34 has the meaning: "Verily only in the sight of Allah is the knowledge of the Day of Resurrection; and He who sends down rain, and 
knows what is in the womb. And no one can know (for certain) what he will do tomorrow. And no one can know on what earth he will die. Truly, Allah is All-Knowing, All-Knowing. " (Indonesian Ministry of Religion, 2007).

\section{The Influence of the Global Stock Market Against the Indonesian Sharia Stock Market for the 2013-2017 period in the Short Term}

The estimation of the short-term ECM model based on Table 6 shows valid results with a coefficient of RESID01 (-1) of -0.271698 and a probability value of 0.0023 which is smaller than $\alpha(0.05)$. The RESID01 coefficient (-1) of -0.271698 shows that the effect in the short term corrects $27 \%$ of past errors for its long term effect. The error correction magnitude of -0.27 indicates an adjustment in the previous period to correct changes in the ISSI variable towards equilibrium in the next period of 18.5 months or 1.5 years.

Simultaneously, the P-value for the $F$ test statistic shows a value of 0.002333 or smaller than $\alpha$ of 0.05 , which means that it is simultaneously significant in the short term. While partially, only the DJIA index has a significant effect on ISSI. In Table 4 the P-value for the $t$ test variable $D$ variable (DJIA) is 0.0101 , smaller than $\alpha$ of 0.05 so it can be said that $D$ (DJIA) has a significant effect on ISSI. Equation 4 explains that an increase in the DJIA index by one unit will increase ISSI by 0.003109 . The adjusted R-square value of 0.222663 , means that the diversity of the dependent variable in the model can be explained by the independent variables of $22.2663 \%$, the remaining $77.7337 \%$ is explained by other variables not in the model.

Research from Nurwulandari and Fuadi (2013) concluded that the DJIA index does not have an influence on changes in short-term balance but the value is positive, unlike the research conducted by (Andiyasa et al., 2014) which states the DJIA index has a significant positive effect on the CSPI. The difference is very reasonable due to various factors, one of which is the difference in the chosen research period. In the world of stock markets the movement of stock indexes is more visible in the short term because every day there are fluctuations in transactions that occur, causing movements.

The results of this study indicate that the short-term effect corrects the long-term effect and only the DJIA index has a significant positive effect on ISSI in the short term, while the N225 and HSI indices have no significant effect on ISSI in the short term. The DJIA index has a strong role in the changes that occur in the global stock market at any time, especially on the Indonesian sharia stock market in the 2013-2017 period. Stock investors generally refer to the movement of the American stock market because the world economy tends to make the conditions and policies of the American economy a benchmark.

There are still many investors who only pay attention to the macro fundamental factors in the form of the DIIA index with the aim of getting profits from the sale and purchase of shares in the short term, so it can be said that these investors are speculating. The speculators take advantage of rising and falling stock prices due to stock market sentiment. 
Speculation has a negative impact on the culprit or other investors. It has been mentioned by the Shariah National Council of the Indonesian Ulema Council (Majelis Ulama Indonesia) (2003) in a fatwa that prohibits speculation because it does not apply the precautionary principle and contains elements that are prohibited from sharia. Allah says in Surah Al-Maidah verse 90, "O believers! Indeed, alcoholism, gambling, (sacrificing for) idols, and drawing fate with arrows, are abominable and include the actions of the devil. So stay away (actions) so that you are lucky. " (Indonesian Ministry of Religion, 2007).

\section{CONCLUSION}

The conclusions that can be drawn based on the results of research on the analysis of the influence of the global stock market on the Indonesian Islamic stock market with the Error Correction Model (ECM) approach are global indices such as the Dow Jones Industrial Average (DJIA), Nikkei 225 (N225), and the Hang Seng Index (HSI) has a significant effect on the Indonesian Syariah Stock Index (ISSI) in the long run. Estimation of the short-term ECM model shows valid results, showing that the effect in the short term corrects $27 \%$ of past errors for their long-term effects. The magnitude of error correction of -0.27 indicates an adjustment in the previous period to correct changes in the ISSI variable towards equilibrium in the next period of 18.5 months or 1.5 years. Simultaneously, DJIA, N225, and HSI have a significant influence on ISSI in the short term, while only partially DJIA has a significant influence on ISSI. DJIA was able to explain the diversity of ISSI by $22.2663 \%$, while $77.7337 \%$ was explained by other variables not in the model.

The presence of this research is expected to make the government and parties related to the capital market increase the Islamic stock index in Indonesia. In addition, there needs to be attention and control over speculative practices that exist in the capital market in Indonesia. Judging from the results of the analysis, the DJIA index, N225, and HSI need to be a concern for investors in Indonesia. This is because in the long run the index affects ISSI. Research needs to be held again in the future. The ECM method can be used, but it is better to use stock index data changes in the form of daily or weekly data in order to get more accurate results and use the global sharia index as the independent variable.

\section{REFERENCES}

Adlan, M., \& Mawardi, I. (2018). ANALISIS PENGARUH UTANG BERBASIS BUNGA DAN PENDAPATAN NON-HALAL TERHADAP NILAI PERUSAHAAN EMITEN SAHAM SYARIAH. Jurnal Ekonomi Dan Bisnis Islam (JEBIS), 4(2), 103-128. https://doi.org/10.20473/jebis.v4i2.10035

Andiyasa, I. G. A., Purbawangsa, I. B. A., \& Rahyuda, H. (2014). Pengaruh Beberapa Indeks Saham dan Indikator Ekonomi Global terhadap Kondisi Pasar Modal Indonesia. E-Jurnal Ekonomi Dan Bisnis Universitas Udayana, 3(4), 182-199.

Antonio, M. S., Hafidhoh, H., \& Fauzi, H. (2013). The Islamic Capital Market Volatility: A Comparative Study Between in Indonesia and Malaysia. Buletin Ekonomi Moneter Dan Perbankan, 15(4), 391-415. https://doi.org/10.21098/bemp.v15i4.73

Ariefianto, M. D. (2012). Ekonometrika Esensi dan Aplikasi dengan Menggunakan EViews. 


\section{Penerbit Erlangga.}

Darmadji, T., \& Hendy, M. F. (2011). Pasar Modal Indonesia. Salemba Empat.

Departemen Agama RI. (2007). Al-Qur'an dan Terjemahnya. Syaamil Cipta Media.

Dewan Nasional Syariah Majelis Ulama Indonesia. (2003). Fatwa Dewan Syariah Nasional NO: 40/DSN-MUI/X/2003.

Dornbusch, R., Park, Y. C., \& Claessens, S. (2000). Contagion: Understanding How It Spreads. The World Bank Research Observer, 15(2), 177-197. https://doi.org/10.1093/wbro/15.2.177

Dzanurrahmana Zein, F., Aimmatul Umah, K., Asyaria, K., Herianingrum, S., Syifaul Qulub, A., \& Alif Rusmita, S. (2019). Optimization of ISSI Stock Portfolio using Single Index Models in 2013-2017. KnE Social Sciences, 3(13), 346. https://doi.org/10.18502/kss.v3i13.4215

Ekananda, M. (2016). Analisis Ekonometrika Time Series. Mitra Wacana Media.

Frensidy, B. (2013). Lihai Sebagai Investor. Salemba Empat.

Gujarati, D. (2004). Basic Econometrics (Ekonometrika Dasar). Penerbit Erlangga.

Jansen, W. J. (1996). Estimating saving-investment correlations: Evidence for OECD countries based on an error correction model. Journal of International Money and Finance, 15(5), 749-781. https://doi.org/10.1016/0261-5606(96)00034-4

Majdoub, J., Mansour, W., \& Jouini, J. (2016). Market integration between conventional and Islamic stock prices. North American Journal of Economics and Finance, 37, 436-457. https://doi.org/10.1016/j.najef.2016.03.004

Mawardi, I., Widiastuti, T., \& Sukmaningrum, P. S. (2019). The Impact of Macroeconomic on Islamic Stock Prices: Evidence from Indonesia. The 2nd International Conference on Islamic Economics, Business, and Philanthropy (ICIEBP) Theme: "Sustainability and Socio Economic Growth," 499-509. https://www.knepublishing.com/index.php/KneSocial/article/view/4226/8683

Murti, W. (2017). The Effects of Gold Prices, the Hang Seng Index, and the Dow Jones Index on the Composite Stock Price Index (CSPI) in Indonesia. International Journal of Economic Perspectives, 11(2), 258-266.

Nurwulandari, A., \& Fuadi, I. (2013). Pengaruh Keseimbangan Jangka Panjang Dan Jangka Pendek Indeks Djia, Ftse 100, Dax 30, Cac 40 Dan Nikkei 225 Terhadap Indeks Harga Saham Gabungan (Ihsg). Jurnal Ilmiah Akuntansi Dan Bisnis, 8(1), 9-11.

Pasaribu, R. B. (2008). Financial Distress Prediction in Indonesia Stock Exchange-Case Study of Trade Industry Public Company. Journal of Economics, Business, and Accounting, 11(2).

Rusmita, S. A., Muharam, I. N., Rani, L. N., \& Cahyono, E. F. (2019). Dynamics relationship between the composite and Islamic index in the capital market of Indonesia. Proceedings of the 3rd Global Conference on Business Management \& Entrepreneurship (GC-BME 3), 442.

Rusmita, S. A., Salleh, M. C. M., Sukmaningrum, P. S., \& Zulaikha, S. (2019). Growth and Value Effect on Jakarta Islamic Index: Analysis towards Performance of Sharia Equity Mutual Fund. Al-lqtishad: Jurnal Ilmu Ekonomi Syariah, 11(1), 153-165.

Rusmita, S. A., Syafira, F. N., \& Afifa, O. M. (2020). The Effect of Environmental Disclosures on ISSI Company Stock Prices. International Journal of Innovation, Creativity and Change, 10(12), 488-501.

Sugiarto. (2009). Struktur Modal, Struktur Kepemilikan Perusahaan, Permasalahan Keagenan dan Informasi Asimetri. In Graha Ilmu, Yogyakarta. (Vol. 1, Issue 9). Graha IImu.

Sugiyono. (2014). Metode Penelitian Bisnis (Pendekatan Kuantitatif, Kualitatif, dan R\&D). 
Alfabeta.

Tandelilin, E. (2010). Portofolio dan Investasi Teori dan Aplikasi (Edisi Pert). Kanisius.

Umam, A. K., Ratnasari, R. T., \& Herianingrum, S. (2019). The Effect Of Macroeconomic Variables in Predicting Indonesian Sharia Stock Index. Jurnal Ekonomi Dan Bisnis Islam (JEBIS), 5(2), 223-240. https://doi.org/10.20473/jebis.v5i2.15031 